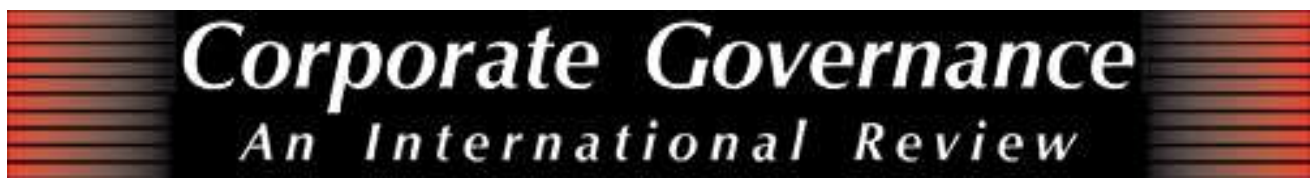

\title{
Private Equity Takeovers and Employment in the UK: Some Empirical Evidence
}

\begin{tabular}{|r|l|}
\hline Journal: & Corporate Governance: An International Review \\
\hline Manuscript ID: & CGIR-2010-0093PE.R3 \\
\hline Manuscript Type: & Private Equity Issue \\
\hline Keywords: & $\begin{array}{l}\text { Mergers \& Acquisitions < Market Control Mechanisms, United } \\
\text { Kingdom < National Economies, Agency Theory < Corporate } \\
\text { Governance Theories }\end{array}$ \\
\hline \multicolumn{2}{|l}{} \\
\hline
\end{tabular}

\section{SCHOLARONE \\ Manuscripts}




\title{
PRIVATE EQUITY TAKEOVERS AND EMPLOYMENT IN THE UK: SOME EMPIRICAL EVIDENCE
}

\begin{abstract}
Manuscript Type: Empirical

Research Issue: This study investigates the employment consequences of private equity acquisitions, in particular institutional buy-outs (IBOs), in the UK. It involves a pre and postacquisition analysis of employment and performance characteristics for a sample of acquired firms and a matched sample of non-acquired firms.

Research Findings: There is a significant decrease in employment in acquired firms in the year immediately after the completion of the IBO compared with non-acquired firms. Further analysis fails to identify any parallel or subsequent increase in firm productivity or profitability. This evidence suggests that the observed downsizing has not been effective either in disciplining staff or imparting a clearer focus to activities.

Academic Implications: The results of this study add to our understanding of the employment effects of private equity acquisitions, especially IBOs. Two important theoretical issues emerge. The first is a need to conceptualize skills and human capabilities on a collective dimension, specific to a particular organizational setting, and the extent to which they contribute to the organization's performance. The second is the importance of understanding managers as operating in particular social settings, making subjective choices based on their specific knowledge and experiences.

Practitioner Implications: The main practitioner implication of our study is that companies acquired via IBO do not exhibit increased productivity or profitability in the wake of a significant reduction in employment. This highlights the need for new management to better understand the link between employment and performance in the specific corporate setting of the acquired firm.




\section{PRIVATE EQUITY TAKEOVERS AND EMPLOYMENT IN THE UK: SOME EMPIRICAL EVIDENCE}

\section{INTRODUCTION}

There is an emerging research interest in the relationship between governance, sources of company finance and the consequences for employees, with existing work predominantly focusing on comparisons of the effects of national regulatory regimes (Botero, Djankov, La Porta, Lopez-de-Silanes, \& Shleifer, 2004; Goergen, Brewster, \& Wood, 2009). Such issues tend to become especially highlighted in the case of takeovers of public companies by private equity investors. Private equity acquisitions have been on the increase since the late 1990s (Renneboog, Simons, \& Wright, 2007) and the increased takeover activity by private equity houses has been causing public concern about its consequences. While the involvement of private equity in the takeover of public companies traditionally focused on relatively small companies, often facilitating management buy-outs, more recent transactions have highlighted the potential for some of the largest UK companies to be the targets of such acquisitions (e.g. Alliance-Boots). Indeed, Thornton (2007) suggests that as many as 20 per cent of all private sector workers in the UK are employed by organisations with some private equity investment. This has raised concerns about the welfare of substantial numbers of employees with employee representatives calling both for greater transparency from private equity acquirers and legislative changes to safeguard employee rights. For example, on 24 February 2007, Brendan Barber, the General Secretary of the Trades Union Congress (TUC), challenged private equity investors to attend a roundtable and "to tell [the public] what they stand for and whether they accept any responsibilities to their workforce or the wider community" (Barber, 2007:1). 
The objective of this study is to investigate the impact of private equity acquisitions on employment and employees in a sample of UK private equity acquisitions. Our study focuses specifically on institutional buy-outs (IBOs). We examine whether there are changes to employee numbers, employee productivity, employee remuneration as well as profitability both in the years prior to the acquisition and in the post-acquisition period. We also utilise an industry and size-matched control sample of non-acquired firms in order to isolate precisely the employment consequences of our sample of private equity acquisitions. Our study provides an important and contemporary empirical contribution to the ongoing public debate on the impact of private equity acquisitions and also serves as a useful contribution to existing academic research on the employment consequences of corporate takeovers.

Much of the existing research on the employment consequences of takeovers has been motivated by the Shleifer \& Summers (1988) seminal article where they argued that a change in ownership permits new management to renegotiate the implicit contracts of employment of existing workers resulting in a breach of trust insofar as it violates prior expectations attached to employees' implicit labour contracts. Subsequent research has sought to address this question by investigating the impact of takeovers on employment and/or wages both in the context of takeovers generally (e.g. Denis, 1994; McGuckin \& Nguyen, 2001; Conyon, Girma, Thompson, \& Wright, 2001, 2002 and 2004; Beckman \& Forbes, 2004; and Gugler \& Yurtoglu, 2004) and specifically in the context of management buy-outs (MBOs) (e.g. Lichtenberg \& Siegel, 1990; Bacon, Wright, \& Demina, 2004; Amess \& Wright, 2007; Weir, Jones, \& Wright, 2008 and Amess \& Wright, 2010). Overall, there is little consistent support for the Shleifer \& Summers (1988) hypothesis with researchers identifying different findings depending on whether the 
acquisition is hostile or friendly, the type of staff (white collar versus production staff), the extent of post-acquisition divestment, and also the period being studied.

Research examining the employment effects of private equity takeovers is only now emerging in the literature, often forming part of a larger study of takeovers and/or MBOs generally (Amess, Brown, \& Thompson, 2007; Amess \& Wright, 2007 and 2010; Weir et al., 2008). However, studying private equity acquisitions, specifically IBOs, as a homogenous group has potential to take forward our understanding of this increasingly important phenomenon in a number of respects. First, private equity-backed IBOs typically involve the complete replacement of existing managers, hence weakening the social and implicit employment agreements with employees. Consequently, incoming managers are likely to take a more objective view of how best to utilise employees in the pursuit of owner wealth, raising questions about both employment levels and wage levels. Second, private equity-backed IBOs are often financed by significant levels of debt and this debt burden is likely to put additional pressure on management to seek economies, especially in reducing the overall wage bill. Third, it is generally anticipated that private equity acquirers will seek to recover their investment and any profits within a reasonably short time-frame so may be more focused in seeking to eliminate unnecessary costs as soon as possible after the takeover, putting employees and associated costs particularly under the spotlight.

The paper is structured as follows: the next section provides a comprehensive review of prior research on the impact of ownership changes on employment and employees, concluding with a discussion of the likely impact of private equity acquisitions on employment. The following section introduces the sample, variables and outlines the research methodology. This 
is followed by our empirical analysis. Our conclusions, limitations of our study and a discussion of the academic and practitioner implications of our findings are presented in the final section.

\section{OWNERSHIP CHANGES AND THE CONSEQUENCES FOR EMPLOYEES}

Changes in company ownership have been an important area of academic inquiry in the economic and finance literature over the past fifty years. The vast majority of work in the area has focused on the economic impact of takeovers of public companies, initially in relation to changes in market share and the effect of mergers on competitiveness and more recently examining issues surrounding wealth changes, specifically in respect of shareholders in the bidder and target firms. Central to much of this research has been the assumption that takeovers are an important mechanism for achieving the most efficient use of corporate assets (Manne, 1965; Jensen, 1986). This view is further strengthened by the significant premiums acquiring companies pay in order to obtain control of another firm's assets (Andrade, Mitchell, \& Stafford, 2001). In an environment of companies being acquired for prices significantly in excess of their market value, a key question concerns the sources of the expected wealth gains.

In a seminal article, Shleifer \& Summers (1988) argued that one potential source of wealth extraction may come from the target firm's employees since a change in ownership permits new management to renegotiate the implicit contracts of employment of existing workers. How this may occur in practice, in addition to the laying off of staff, has been discussed by a number of researchers. For example, employees may work for lower wages early in their career and remain committed to the organization in the expectation of higher wages as they advance up the salary scale. However, given that older workers are likely to be more 
expensive, firms have an incentive to renege on this implicit arrangement, a process that may be facilitated by a takeover (Beckmann \& Forbes 2004).

Researchers have also suggested that the nature of the takeover may influence subsequent employment. For example, Conyon et al. (2002) argue that the risk of a renegotiation of employment contracts is more likely in the case of hostile acquisitions for two reasons. First, the fact that the incoming management team acquired the firm against the wishes of the company is a clear signal that the new management team would pose a very credible threat in any confrontation with employees. Second, the fact that the management team is new means it is unlikely to have developed any significant ties with existing employees in the same way that the incumbent management team would. Denis (1994) suggests that employees are more likely to come under pressure after a horizontal takeover, where two companies in the same industry come together, because a significant level of duplication is expected to exist after the takeover. Furthermore, Beckmann \& Forbes (2004) suggest that the likelihood of a breach of trust after acquisitions is likely to be positively related to the extent of the bid premium the acquirer has had to pay. The remainder of this section reviews the existing research evidence on the impact of ownership changes on employees. The review begins by looking at the impact of mergers and acquisitions generally and then progresses to focus on the employment impact of MBOs and private equity acquisitions in particular.

\section{Mergers and Acquisitions}

A relatively small number of studies have sought to investigate the impact of mergers and acquisitions on employees. Essentially, these studies focus on the impact of takeovers on employment or the impact on wages, or both. In one of the earliest studies in the US, Denis 
(1994) examines the impact of takeovers on employment between 1975 and 1984. Denis (1994) finds that the number of employees declined significantly after hostile acquisitions in the 198084 period but finds no evidence of post-acquisition declines following takeovers prior to 1980 and for friendly acquisitions between 1980-84. Furthermore, she finds that the reported declines occur in plants originally owned by the acquirer and not the target and suggests these declines are related to broader restructuring by acquirers and not an attempt to breach existing labour contracts. These findings are reinforced by McGuckin \& Nguyen (2001) who report that postacquisition job losses are more likely to occur in larger factories owned by the acquiring firm rather than significantly impacting on the employees of the target. These two studies seem to provide some support for job reductions after takeovers but find no evidence that employees in the acquired company are especially targeted.

Beckman \& Forbes (2004) argue that, if there is a breach of trust subsequent to takeover, then employees may have to pay through lay-offs and wage cuts for excessive bid premiums paid by acquirers. Based on a UK sample, the authors fail to find evidence to support this hypothesis, concluding that rather than a gain by shareholders at the expense of employees, both the new shareholders and employees may be locked in a form of "equal misery" (ibid: 163) following the takeover due to the much documented evidence of acquisitions performing badly. Further, Goergen et al. (2006) found that it was more likely that those firms which have implicit contracts in place renege on these contracts ex post by adopting practices with more damaging effects for their workforce, most notably leaner staffing and hence redundancies. Finally, based on a 20year study of the Californian savings and loans industry, Haveman \& Cohen (1994) found that, in general, mergers tend to destroy jobs and directly increase both exits from the organization and from the industry at large. 
Conyon et al. (2001 and 2002) examine the demand for labour after takeovers in the UK between 1967 and 1996. In a study of the period 1983 to 1996, Conyon et al. (2001) find that demand for labour decreased for all acquirers in the region of 7.5 per cent, but they fail to identify any differences depending on whether the takeover was hostile or friendly. Over the longer term, between 1967 and 1996, Conyon et al., (2002) report significantly larger decreases in the demand for labour arising from hostile and related bids. Based on French data, Margolis (2006) found that, in the case of mergers, employees of the acquired firm were more likely to leave/lose their jobs in the period immediately following the acquisition. Over time, however, these differences disappeared, suggesting that the effects of a takeover are more short-term, even if the effects are carried over to the medium and long terms. Based on a case study of a single organization, Björkman \& Søderberg (2006) argue that mergers can have the effect of diverting managerial attention towards financial outcomes at the expense of the strategic development of the rest of the organization. Indeed, reviews by Andrade et al. (2001) and Tuch \& O'Sullivan (2007) note that mergers do not appear to result in overall organization-wide productivity gains.

Rosett (1990) sought to investigate whether the premiums paid to target shareholders during takeover contests were subsequently reclaimed from employees through less favourable wage settlements. Analysing a large sample of such settlements over the pre- and post-takeover period Rosett (1990) finds little evidence to support this hypothesis. In the UK, Conyon et al. (2004) also investigate the impact of mergers on wage levels and find no evidence that mergers had a negative impact on wage levels. Indeed, Conyon et al. (2004) report that both wages and profitability increased after mergers with related acquisitions being associated with higher wages. Focusing on hostile takeovers, Gokhale, Groshen, \& Neumark (1995) investigate whether takeover targets experience extra-marginal wages prior to being acquired and then go on 
to see whether takeovers result in any subsequent changes. Gokhale et al. (1995) find no evidence of extra-marginal wages being paid to employees prior to the acquisition. However, their study does report a reduction in the relative employment of more tenured (and likely more expensive) workers after the acquisition.

\section{Management Buy-Outs/Private Equity}

It was suggested earlier that the nature of takeovers may influence the subsequent experience of employees. This expectation has prompted researchers to investigate the employment consequences of companies, or parts of companies, that are subject to a management buy-out (MBO) or other private equity related acquisitions. Table 1 summarises these studies including details of the studies as well as summarising the main findings. Two of the earlier MBO studies were undertaken in the US and broadly followed the approach discussed earlier for general mergers and acquisitions research, i.e. comparing employment levels before and after the MBO transaction using public data. Kaplan's (1989) study sought to investigate whether MBOs led to a reduction in employment. He found no evidence of employment reductions, indeed there was evidence that firms increased employment after MBOs. Lichtenberg \& Siegel (1990) focused on testing Jensen's (1989) argument that one way MBOs achieve efficiency is by replacing direct monitoring by large bureaucracies with a more incentive orientated approach. First, Lichtenberg and Siegel (1990) found a very significant decline in the level of employment of non-productive staff (approximately 8.5 per cent) thereby adjusting the production/non-production ratio in favour of productive staff. Second, they found an increase of approximately 3.6 per cent in annual compensation of production workers compared to a slight decline in the compensation of non-production staff. 


\section{INSERT TABLE 1 ABOUT HERE}

More recent studies have approached the investigation of the employment consequences of MBOs/private equity acquisitions from two perspectives. On the one hand, studies such as Amess \& Wright (2007); Amess et al. (2007); Davis, Haltiwanger, Jarmin, Lerner, \& Miranda (2008) and Weir et al. (2008) employ secondary data to ascertain whether changes in employment, wages and productivity can be identified either by comparing firm characteristics before and after the acquisition and/or benchmarking against a non-acquired control group. On the other hand, studies such as Bacon et al. (2004), Bacon, Wright, Demina, Bruining, \& Boselie (2008), Bacon, Wright, Scholes, \& Meuleman (2010) and Bruining, Boselie, Wright, \& Bacon (2005) employ questionnaire surveys to obtain insights on any alternations to HR practices after the acquisition.

As shown in Table 1, there has been significant recent interest in seeking to understand the employment consequences of MBOs/private equity acquisitions. Quantitative studies seeking to ascertain employment consequences have produced mixed results but, on the whole, show little consistent evidence that MBOs/private equity acquisitions have a negative impact on employment. For example, in the UK, Amess \& Wright (2007) find no discernable differences in employment growth rates between LBO firms and non-LBO firms, even though there is some evidence of lower wage growth in the LBO sample. Taking a slightly different perspective, Amess et al. (2007) find that employees in firms subject to MBOs enjoy a greater degree of discretion over their work practices than non-MBO firms. It should be noted that a recent US study by Davis et al. (2008) presents a more negative picture with MBO firms experiencing 
significantly lower employment growth rates than non-MBO firms in the three years after the acquisition. However, in years four and five after the acquisition, Davis et al.'s (2008) study documents a reversal with MBO firms showing significantly higher employment growth rates than their non-MBO counterparts.

A useful recent development in this area of analysis has been an attempt by researchers to disaggregate $\mathrm{MBO}$ acquisitions in terms of sources of finance, specifically seeking to focus on whether private equity-backed deals exhibit different post-acquisition employment characteristics compared to non-private equity transactions. Amess \& Wright (2007) segregate their sample between MBOs and MBIs and find that the post-acquisition employment growth rates in MBIs is significantly lower than for other MBOs. Interestingly, in a subsequent study, Amess \& Wright (2010) segregate their sample of LBO acquisitions between those with private equity involvement and those without and report no significant differences in employment either between private equity-backed LBOs and other LBOs or between private equity-backed LBOs and a control sample of non-LBOs. Finally, Weir et al. (2008) focus on firms acquired in publicto-private acquisitions and report that job losses in their sample firms are at a lower rate than firms in the same industries that remain public.

Using questionnaire surveys of firms having gone through MBOs in the UK, Bacon et al. (2004) find that a significant number of respondents report an increase in the importance of HRM and the resources devoted to it subsequent to MBO. Examples include: increased employment, greater employee involvement, increased training, greater flexibility and increases in share ownership by staff. In subsequent surveys, both in the UK and across Europe, Bruining et al. (2005) and Bacon et al. (2008) reinforce this positive impression of HRM practices after MBOs, specifically reporting an increase in the number of high commitment practices. Bacon et 
al. (2010) look specifically at HR issues after private equity-backed MBOs and find no evidence that the new ownership results in changes to union recognition, union membership density or management attitudes to union membership. Furthermore, Bacon et al. (2010) find a greater level of employee consultation by management after private equity acquisitions.

\section{Private Equity Acquisitions}

Under the broad term of private equity are two fundamentally different types of investor behaviour (Wood \& Wright, 2010). The first, venture capital, involves early stage investors who provide capital in return for input in setting organizational direction. There is a general consensus that the effects of this are generally positive (Wood \& Wright, 2010). In contrast, what is sometimes referred to as private equity per se, is when an investor purchases, or facilitates in the purchase of a firm, on the premise that either new management, or at least a change in managerial style, may enhance returns. In effect, this involves the acquisition of publicly quoted companies and taking them private via so called public to private transactions (PTPs) ${ }^{1}$ or the takeover of non-listed companies by private equity firms.

Following on from a first wave in the 1980s, a second wave from the mid-1990s onwards has attracted much debate and controversy (see Wood \& Wright, 2009). Renneboog et al. (2007) usefully classify such PTP transactions into three sub-groups: (i) management buy-outs (MBOs) where the incumbent management seeks institutional support from private equity firms to purchase a major stake in the firm and to fund the transaction which aims at taking the firm private; (ii) management buy-ins (MBIs) arise where a team of outside managers or entrepreneurs purchase all or most of the equity; (iii) institutional buy-outs (IBOs) represent deals where the bidding group consists solely of institutional investors and private equity houses 
and any equity stake held by management arises from their remuneration package. From an employee perspective, the consequences of MBOs might be expected to be more positive (or less negative) since the existing management team remains suggesting that the existing managementemployee relationship might remain unaltered. ${ }^{2}$ Managers are likely to be bound to their workforce through implicit contracts, and are likely to have sunk emotional capital in the firm. MBIs and IBOs on the other hand typically introduce an external management team who are less likely to be loyal to the existing workforce, especially if employees had opposed the takeover transaction, and might be expected to seek renegotiation of existing employment contracts as hypothesised by Shleifer \& Summers (1988).

In the finance literature, IBOs have long been viewed as a useful mechanism in seeking to reduce the agency problem between widely dispersed shareholders and managers. Specifically, as argued by Jensen (2006) and Wright, Renneboog, Simons, \& Scholes (2006), private equity ownership restores the separation between ownership and control by putting in place active investors who provide more direct scrutiny of managerial behaviour and consequently are expected to deliver greater shareholder-orientated performance. It can be argued that improvements in technology and management techniques mean that firms are capable of operating on far leaner staffing levels than before (Wruck, 2008; Jensen, 2010). Quite simply, as the firm becomes leaner, there is less room for sub-optimal staff to hide. Moreover, measures to reduce the labour intensity of productive processes may result in overall productivity and efficiency gains (Harris, Siegel, \& Wright, 2005). Organizations that lag behind in this process are likely to be rendered uncompetitive (Wruck, 2008; Jensen, 2010). Wruck (2008) argues that IBOs can play an important role in pioneering best practice since they provide evidence of the benefits of dispassionate investor behaviour. When owners, and managers as their agents, have 
fewer personal ties and implicit commitments, they are more likely to promote the inevitable agenda of downsizing and productivity enhancement.

The large premiums associated with such takeovers, typically in excess of 40 per cent, appear consistent with bidders' expectations of significantly improved post-acquisition performance (Renneboog et al., 2007). However, the precise way in which such improved performance is achieved remains unclear. Renneboog et al. (2007:1) argued that "there has been no systematic research on the sources of shareholder wealth gains in UK going private transactions". More recent work has partially redressed this gap (Weir et al., 2008; Guo, Hotchkiss, \& Song, 2010), but evidence on the consequences for employees and other stakeholders remains mixed, suggesting a diversity of outcomes (Wood \& Wright, 2009).

In view of the above, it is possible for us to identify a number of related issues regarding the impact of private equity acquisitions on employment. First, the general literature on mergers and acquisitions, in particular when taking the agency theory perspective, suggests that employees are likely to be adversely affected by a private equity funded takeover. This is expected to arise for a number of reasons. First, such takeovers are likely to facilitate the reigning in of managers, and their closer subordination to the agenda of generating value for owners. Second, changes in ownership are likely to open opportunities for challenging existing ways of doing things and allow for the recasting of relations within the firm which is expected to lead to downsizing and the liquidation of assets. More pragmatically, it could be argued that, as private equity takeovers often target underperforming or failing organizations, job losses will often be inevitable. Moreover, in a general climate of downsizing, a private equity takeover may only hasten the inevitable, leading to organizational restructuring on more favourable terms than 
would be the case if it was deferred (Wruck, 2008). Indeed, when placed on a firmer footing, the organization may have room to prosper and expand its activities, allowing for re-hiring.

Alternatively, more associational approaches would suggest that specific forms of private equity facilitated takeovers may in fact allow managers greater autonomy to harness their insider knowledge as to the skills and capacities of workers, allowing for more focused human resource development and flatter organizations associated with greater worker autonomy. This reflects recent theoretical work that focuses on the relative autonomy possessed by actors to make key strategic choices, particularly at key instances where there are specific opportunities for innovation (Sorge, 2005). In other words, whilst actors operate under constraints in terms of governance and implicit rules, at specific moments, there are opportunities to innovate, forming the basis for new ways of doing things. Having some understanding of the value of existing human capital, they will be more reluctant to liquidate it.

Aoki (2010: 30) argues that, over time, organizations gradually accumulate "cognitive assets". This is more than simply the lump sum of individual human capital as it refers to the skills and capabilities of employees in the context of a particular "mode of associational cognition" (ibid.: 30). The latter refers to how human assets are related to each other and the context in which they operate (ibid.: 31). In other words, Aoki (2010) argues that individuals do not only possess externally marketable (and, hence, costable) skills, but also specific knowledge and capabilities relevant to the firm they operate in. This knowledge and these capabilities allow for firm specific complementarities when used in conjunction with peers' own knowledge sets. This is very difficult for outsiders to cost accurately but explains why existing managers are likely to have closer ties and implicit agreements with workers, which they may be reluctant to renege on. In other words, managers do not hang on to surplus staff in the interests of personally 
motivated empire building, but because they are better equipped to cost the worth of the firm's human capabilities as a whole. In contrast, in the case of MBIs, the ejection of the existing management team means that such ties are weakened and, as a consequence, it will be harder for a new management team to accurately cost human and collective cognitive capital. As a result, it is likely that efficiency gains will be sought through sweating rather than nurturing human assets. As noted earlier, private equity-backed IBOs typically involve changing the management team and reducing the social and implicit employment agreements with employees.

This leads to two alternative propositions. The first is that IBOs are likely to result in greater job shedding, given that this provides an effective means of solving the agency problem, and reversing accumulated managerial empire building. Such job shedding will also facilitate significant productivity enhancements. The second is that whilst IBOs are likely to result in greater job shedding, owing to the weaker ties that will exist between a new managerial team and rank-and-file workers, this will not result in productivity enhancements. Rather, as new managers will not be able to accurately cost the cognitive capabilities of the firm's employees, this will result in accumulated assets being sacrificed for short-term gain.

\section{SAMPLE, VARIABLES AND METHODOLOGY}

Our sample of private equity acquisitions covers the period 2000 to 2006 in the UK. We first downloaded the list of IBOs from the Deals module in Thomson One Banker. In a second stage, we verified whether all acquisitions were indeed IBOs. As a result some acquisitions were excluded from the initial list. In a third stage, we included acquisitions that had been left out from the initial list. These were acquisitions that Thomson One Banker considered to have been made by strategic investors rather than institutional investors. Thomson One Banker defines the 
former as long-term investors whereas the latter typically have shorter horizons. As we found this definition somewhat arbitrary, we decided to include these additional acquisitions in our sample. We arrived at a total of 73 acquisitions of UK public companies completed over the period 2000 to 2006. Table 2 provides a breakdown of the industrial classification of our sample of acquisitions.

\section{INSERT TABLE 2 ABOUT HERE}

Since our objective was to investigate issues surrounding employment and employees before and after the takeover we sought to collect data for each firm for three years prior to the takeover and three years after the completion of the acquisition, providing us with a seven year window surrounding the acquisition. Table 3 provides a breakdown of the 73 takeovers we include in our analysis in terms of year of acquisition. In what follows, we define year 0 as the year when the acquisition was completed and all other years are expressed relative to year 0. For example year -1 denotes the year preceding the year of the acquisition.

In order to assess the effects on performance and the number of employees of the private equity acquisition, we attempted to match each of our sample firms with a non-acquired firm with the same three-digit SIC code and the closest turnover (our measure for firm size) in year 0 (or year -1 if the year 0 turnover figure was not available for the sample firm) ${ }^{3}$. Finally, each control firm had to survive until year 2 at least. We were able to match 66 of our sample firms following the above criteria. Another two sample firms could be matched with a control firm that survived only until year 1 . Table 3 shows the breakdown of control firms across time. 
INSERT TABLE 3 ABOUT HERE

In order to adequately address our research objectives we set out to obtain data on our sample of acquisitions both before and after the completion of the acquisition. Since we are focusing on public companies acquired by private equity houses, i.e. institutional buy-outs (IBOs), obtaining data on the firms for the three years prior to acquisition was not a problem as the annual reports and accounts of listed companies are easily obtained. However, of the 73 firms in our sample, six were acquired within three years of their initial listing and one was acquired within two years of its initial listing, leaving us with available data covering all three years prior to the takeover for 67 firms, two years data for 72 firms and one year data for 72 firms.

Since we are focusing on private equity takeovers, once the firm is acquired it is typically de-listed from the stock exchange and becomes a private company. This significantly complicates the collection of data as it is not easy to trace and/or identify the private firm. In order to overcome this we undertook exhaustive checks of both the Companies House database as well as the FAME database in order to locate the acquired firm. This resulted in us being able to locate usable post-acquisition data for 48 firms for the year after the year of acquisition and 50 firms and 42 firms for years 2 and 3, respectively. The main source of data was each company's annual report and accounts. For a number of companies it simply proved impossible to trace the company post-acquisition; for others we actually found the post-acquisition records but they did not contain data on our key variables. Finally, for a small number of firms, even though the financial records were located, the size and operation was so different from the pre-acquisition firm we decided any comparisons would be meaningless so these were excluded. Table 4 
contains a summary of the number of firms we were able to source useful data on for the preand post-acquisition periods. The table also shows the equivalent statistics for the control firms.

\section{INSERT TABLE 4 ABOUT HERE}

In what follows, we perform a quantitative analysis to identify the effects of IBOs on firm performance, employment and productivity. While the size of our sample prevents us from estimating a labour demand function as in e.g. Conyon et al. (2001 and 2002), we nevertheless include in our univariate analysis all the variables that would be included in such a function. In detail, Conyon et al. (2001 and 2002) base themselves on Nickell (1984) and assume that firms have quadratic cost functions, a Cobb-Douglas technology and are output constrained. Under these assumptions, employment can then be described by the following adjustment equation:

$$
L_{i t}=\alpha L_{i, t-1}+\beta_{1} Q_{i t}+\beta_{2} Q_{i, t-1}+\delta_{1} w_{i t}+\delta_{2} w_{i, t-1}+\gamma_{i}+\eta_{t}+\varepsilon_{i t}
$$

where $L_{i t}, Q_{i t}$ and $w_{i t}$ are the logarithm of employment, the logarithm of real output and the logarithm of real wages relative to the user cost of capital, respectively; $\gamma_{i}, \eta_{t}$, and $\varepsilon_{i t}$ are the firmspecific effects, the time-specific effects and an error term. In what follows, we measure employment by the annual growth rate in the number of employees (Table 5), output by turnover (Table 8) and wages by the total of wages and salaries (Table 9). We also include two measures of profitability, i.e. profit over turnover (Table 6) and profit over employees (Table 7). 


\section{FINDINGS}

\section{Empirical Analysis}

Table 5 reports descriptive statistics on the growth rate in the number of employees for each of the two years before the acquisition and each of the three years following the acquisition. We lose the first year of data, i.e. year -3 , given that we need two years to calculate each annual percentage change in employment. The mean and median growth rates are reported separately for the sample firms and the control firms, respectively, in Panel A. Panel B contains the test statistics for the difference in means (medians) between each pair of adjacent years for the sample companies and the control companies, respectively. The test statistics used consist of a two-tailed t-test for the difference in means and a non-parametric Wilcoxon sign-rank test for the difference in medians. Finally, Panel $\mathrm{C}$ contains the equivalent test statistics for the difference in means (medians) between the sample companies and the control companies for each of the individual years. In other words, Panel B enables us to compare the growth in employment across time for a given type of firms (the sample firms or the control firms) whereas Panel C enables us to compare the growth in the number of employees between the sample firms and the control firms.

Panel A suggests that, when the median growth rate in the number of employees is considered, the control companies experience a slow, but steady increase in employment until year 3 when employment decreases by more than one percentage point. However, the median growth rate in employment is much more volatile for the sample companies. The median company experiences an increase in the number of employees of roughly 3 per cent in year -2 , no change in year -1 and a decrease of -3 per cent in year 1 . After year 1 , the growth rate is back to the levels experienced in the control firms. In contrast, mean growth rates are much more volatile 
for both the sample companies and the control companies. Nevertheless, the means still suggest that there is a reduction in employment in the sample firms in the year following the private equity acquisition, but no such reduction in the control companies. Surprisingly, the control firms experience a drop in employment in year 3.

Panel B of Table 5 suggests that there is a significant decrease in employment in the sample companies from the year preceding the acquisition to the year following the acquisition. The difference in growth is significant at the 10 per cent confidence level, but only if the median is considered. There is no such significant decrease for the mean growth rate. Finally, there is some evidence that the growth in employment slows downs significantly over the years following the acquisition for the control firms. Indeed, the mean difference in the growth rates between year 1 and year 2 and the median growth rates between year 2 and year 3 are significant at the 10 per cent level and the 5 per cent level, respectively. To summarise the results so far, there is some evidence of a significant decrease in employment in the sample companies around the time of their acquisition. However, employment numbers also seem to evolve in cycles as evidenced by the significant decrease in employment in the control firms in year 3 .

More importantly, Panel $\mathrm{C}$ shows that there is a significant difference in the growth rate in employment in year 1 between the sample companies and the control companies. This is the case for both the t-test for the difference in means and the Wilcoxon sign-rank test for the difference in medians: both test statistics are significant at the 5 per cent level. Further, while Panel B suggested that there are cycles in the employment in both the sample companies and the control companies, these cycles are not reflected in the form of significant differences between the two types of companies in Panel C. In other words, whereas Panel B showed some evidence of a significant drop in employment in the control companies in year 3, Panel $\mathrm{C}$ suggests that 
there is no significant difference in the employment growth rate between the sample companies and the control companies in year 3. Hence, the results in Table 5 indicate that private equity investors reduce employment in their target firms after the acquisition.

\section{INSERT TABLE 5 ABOUT HERE}

The question that now arises is whether the observed reduction in the number of employees is reflected in an increase in profitability and productivity. Table 6 reports descriptive statistics for the ratio of profit to turnover, our first measure of profitability. When the average profit over turnover ratio is considered, both the sample companies and the control companies seem to experience clear cycles in their profitability. However, the cycles seem out of sync. In other words, profitability is down for the sample firms during the years preceding their acquisition while it is down for the control firms during the years following the acquisition. This is in line with what was observed in Table 5 for the percentage change in the number of employees. However, when the focus is on the median profit over turnover ratio rather than the mean ratio both the sample companies and the control companies experience fairly stable profit rates. Panel B suggests that the control firms experience a significant decrease in profitability at the 10 per cent level between year 1 and 2 based on the mean ratio. However, there is no such significant difference for the median ratio. Panel $\mathrm{C}$ shows that the economic differences in profitability between the sample companies and the control companies observed in Panel A are not statistically significant. Hence, while Table 5 revealed a significant decrease in employment in the private equity targets after the acquisition this decrease is not reflected in an increase in profitability. 


\section{INSERT TABLE 6 ABOUT HERE}

Table 7 is based on the alternative measure of profitability, i.e. profit per employee. Similar to Table 6 , the median rates of profitability are fairly comparable across the sample companies and the control companies. However, there are differences in the mean rates of profitability. While the mean profitability of the sample companies is fairly constant over time with a small dip around the time of the acquisition, control firms experience much higher volatility in profitability with higher profitability during years -3 to 1 followed by a severe drop in profitability in year 2 and a small loss per employee in year 3. However, Panels B and C do not suggest that there are any significant differences across time or between the sample companies and the control companies. Hence, neither Table 6 nor Table 7 suggests that targets of private equity acquisitions perform significantly worse when compared to non-acquired firms in the same industry and of a similar size as measured by turnover. Again, the sample companies seem to be at a different stage in their profitability cycle than the control companies.

INSERT TABLE 7 ABOUT HERE 
Table 8 reports descriptive statistics for our output or productivity measure, i.e. turnover over employees. Similar to the previous tables on profitability rates, the medians are fairly comparable between the sample and control companies. Also in line with the previous tables, there are clear economic differences in the means between the sample firms and the control firms. However, there are no statistically significant differences across time or between the two types of companies.

\section{INSERT TABLE 8 ABOUT HERE}

Looking at the evidence presented in tables 5 to 8 above in the context of our original propositions we find support for the second proposition and not for the first. In other words, while we document a significant reduction in employment in target firms after IBOs, this is not followed by improvements either in the profit or productivity of these firms.

Table 9 contains descriptive statistics for the wages per employee. When the wages of the median employee are considered, there are virtually no differences between the sample companies and the control companies. However, the wage of the average employee experiences an increase over years -1 to 3 for the control companies but not for the sample companies. Still, Panels B and C do not provide any evidence of significant differences across time or between the sample companies and the control companies. Hence, there does not seem to be any evidence that employees of IBOs lose out via a reduction in their wages.

INSERT TABLE 9 ABOUT HERE 
Following Smart \& Waldfogel (1994), we perform a robustness check to test whether there is indeed no difference in performance between the sample companies and the control companies. The test consists of calculating the difference in the unexpected performance changes between the sample companies and the control companies. So far, we have performed two types of test. First, we compared the performance across time for the sample companies (as well as the control companies). This is a fairly rudimentary test as it does not properly adjust for cycles in profitability. In other words, if private equity targets are taken over when their performance is below the historical average then one would expect an improvement in performance after the acquisition independent of whether private equity investors create value or not. Second, we compared the sample companies to the control companies for each of the three years preceding the acquisition as well as each of the three years following the acquisition. This second test is an improvement on the first test which assumed that any increase in profitability is uniquely due to the acquisition. Conversely, the second test adjusts for the possibility that both the acquired firm and the control firm (i.e. the whole industry) may experience a profitability shock. However, this second test assumes that any industry-wide shock in performance will be the same across the acquired and non-acquired firms. Hence, Smart \& Waldfogel (1994) suggest using a more general model to compare the performance of acquired and non-acquired firms consisting of what they call the difference in surprises. The difference in surprises consists of taking the difference between the actual performance for a given year after the acquisition and the performance forecast for the same year made before the acquisition of the sample firm minus the equivalent difference for the control firm. In other words, the difference in surprises consists of the difference in unexpected changes in performance between the acquired firm and the nonacquired firm. In line with Smart \& Waldfogel (1994), we measure performance by the ratio of 
profit over turnover. However, the main issue with this test is that the data requirements are substantial. Indeed, it requires that analyst forecasts dating back to the year before the acquisition exist for both the acquired firm and the control firm. This is not always the case for various reasons. In particular, the sample firm (as well as the size-matched control firm) may be too small to attract an analyst following. Further, while some firms may have an analyst following, a performance forecast is not always made for every financial year. Finally, for some firms there is a forecast for the profit, but not for turnover.

Forecasts were obtained from Datastream (IBES) for the year preceding the acquisition. The forecasts are the mean analyst forecasts for profit and for turnover. The forecasts refer to years 1, 2 and 3 after the acquisition. Table 10 contains the results of this robustness check. We were able to compute the difference in surprises for 14 of our sample firms and the equivalent control firms for year 1 , nine firms for year 2 and only one firm for year 3. Panel A of the table shows that while there is a small difference in the mean surprise for years 1 and 2, there is no such difference when the median surprise is considered. The t-test as well as the non-parametric Wilcoxon test in Panel B suggests that the difference in surprises is not statistically significant at any of the usual levels of confidence. Hence, while this additional test suffers from a small number of observations it nevertheless confirms our previous results that there is no difference in performance between the sample firms and the control firms.

INSERT TABLE 10 ABOUT HERE 


\section{CONCLUSIONS}

The documented increase in the takeover of public companies by private equity firms in recent years has raised important questions about the consequences of such acquisitions for employees of the acquired firms. In light of these concerns this study has undertaken an investigation of the impact of private equity takeovers on employees in a sample of acquired firms as well as a size and industry-matched sample of non-acquired firms. A key innovation of our study is the focus on a particular category of private equity acquisition, institutional buy-outs (IBOs). There is much public and trade union concern about the potential for these transactions to have negative employment consequences.

The main finding from our empirical analysis is that employment in acquired firms reduces significantly in the year immediately after the completion of the IBO transaction compared to non-acquired firms. However, further analysis fails to identify any parallel or subsequent increase in productivity or profitability. In other words, downsizing does not appear to be effective either in disciplining staff or in imparting a clearer focus to activities. There are two possible reasons for this. The first is simply that job losses may have knock on effects on the morale of remaining staff (Redman \& Wilkinson, 2006). The second is that a new management team imposed through an IBO will lack detailed insider knowledge as to the firm's "cognitive assets" (Aoki, 2010: 30-31). Rather than reversing perversely motivated empire building, restructuring may result in a loss of such accumulated capabilities; hence, any gains through the discipline and more effective divisions of labour will be offset.

Even though we believe our analysis represents a very significant contribution to the ongoing debate about private equity and employment, we are also aware of some limitations in our analysis. First, while we sought to include all IBOs taking place in the UK between 2000 and 
2006, we appreciate that our findings may not be generizable to periods before 2000. Second, we are also aware that following acquired firms for periods longer than three years after the acquisition is capable of improving further our understanding of the employment consequences of such acquisitions. Therefore, future research could usefully investigate the employment consequences of IBOs over a longer period of time, especially periods sufficiently long to enable a better understanding of the role of such acquisitions in the overall life-cycle of the target firms. Third, it is worth noting that some acquired firms who go through a significant reorganisation subsequent to the acquisition will not have been included in our analysis since we relied on the availability of financial statements subsequent to acquisition for much of our data. In other words, this sample selection or attrition bias may actually hide the true extent of employment reduction subsequent to IBO. Fourth, since this is an initial assessment of the consequences of IBOs on employment, we thought it best to use both industry and size to select our matched sample of non-target firms. Future research could also examine the potential for matching a control sample of firms based on pre-bid performance to provide a further dimension to our understanding of the role of pre-bid performance on the likelihood and consequences of IBOs. Finally, our study focuses exclusively on IBOs in the UK so future research could seek to replicate our investigation in other countries.

We believe a number of important theoretical and practical implications emerge from our findings. First, there is a need to conceptualize skills and human capabilities not only on an individual, but on a collective dimension, specific to a particular organizational setting, rather than the lump sum of what individuals may be worth on the external labour market (Aoki, 2010). In the case of private equity funded takeovers that do not involve the existing management team, this may result in the human capabilities of the organization being undervalued. Second, our 
findings underline the importance of understanding managers not just as slaves to universal personal drives (personal wealth and esteem through empire building), but also as operating in particular social settings, making subjective choices based on their specific knowledge and experiences of past events (see. Simmel,1981). Therefore, those with more insider knowledge of the firm, as opposed to a completely new incoming managerial team, are more likely to have a more detailed and nuanced understanding of past events in the organization's history and, as a result, be better able to formulate organizational strategies that draw on the wisdom that may flow from such experiences. A takeover by 'outsiders' may result in this organization-specific learning being discarded, offsetting any gains from efficiency savings that may be garnered by new managers with less sunk emotional capital in the firm. This highlights the need for new management to better understand the link between employment and performance in the specific corporate setting of the acquired firm. Finally, when viewed in the context of other recent work in the field, our findings justify the usefulness of segregating private equity acquisitions into different categories as each may have different employment consequences. 


\section{ENDNOTES}

1 The European Venture Capital and Private Equity Association (EVCA) defines public-toprivate transactions as "a transaction involving an offer for the entire share capital of a listed company by a new company and the subsequent re-registration of that target company as a private company".

2 As discussed in the literature review earlier.

3 The average (median) turnover for the sample companies is $£ 207 \mathrm{~m}(£ 69.2 \mathrm{~m})$ compared to $£ 242.2 \mathrm{~m}$ (£77.7) for the control companies. The differences in means and medians are not statistically significant at any conventional level. 


\section{REFERENCES}

Amess, K., and Wright, M. 2007. The wage and employment effects of leveraged buy-outs in the UK, International Journal of the Economics of Business, 14 (2): 179-195.

Amess, K. and Wright, M. 2010, Leveraged buyouts, private equity and jobs, Small Business Economics, forthcoming.

Amess, K., Brown, S., and Thompson, S. 2007. Management buy-outs, supervision and employee discretion, Scottish Journal of Political Economy, 54 (4): 447-474.

Andrade, G., Mitchell, M., and Stafford, E. 2001. New evidence and perspectives on mergers, Journal of Economic Perspectives, 15 (2): 103-120.

Aoki, M. 2010. Corporations in evolving diversity. Oxford: Oxford University Press.

Armour, A, Deakin, S., and Konzelmann, S. 2003. Shareholder primacy and the trajectory of UK corporate governance, British Journal of Industrial Relations, 41 (3): 531-555.

Bacon, N., Wright, M., and Demina, N., 2004, Management buy-outs and human resource management, British Journal of Industrial Relations, 42 (2): 325-347.

Bacon, N., Wright, M., Demina, N., Bruining, H. and Boselie, P. 2008. The effects of private equity and buy-outs on HRM in the UK and the Netherlands, Human Relations, 61(10): 1399-1433.

Bacon, N., Wright, M., Scholes, L. and Meuleman, M. 2010, Assessing the impact of private equity on industrial relations in Europe, Human Relations, 63 (9): 1343-1370.

Barber, B. 2007, TUC challenges private equity to talks, available at: http://www.tuc.org.uk/economy/tuc-12983-f0.cfm.

Beckman, T., and Forbes, W. 2004. An examination of takeovers, job loss and wage decline within UK Industry, European Financial Management, 10: 141-165. 
Björkman, I., and Søderberg, A. 2006. The HR function in large-scale mergers and acquisitions: the case study of Nordea, Personnel Review, 35 (6): 654-670.

Botero, J., Djankov, S., La Porta, R., Lopez-de-Silanes, S., and Shleifer, A. 2004. The regulation of labor, Quarterly Journal of Economics, 119: 1339-1382.

Boyer, R. 2009. History repeating for economists, Annual Conference of the Society for the Advancement of Socio-Economics, Paris.

Bratton, J. 2003. The context of human resource management, in Bratton, J. and Gold, J. (eds.), Human resource management: Theory and practice. London: Palgrave.

Bruining, H., Boselie, P., Wright, M. and Bacon, N. 2005. The impact of business ownership change on employee relations: buy-outs in the UK and The Netherlands, The International Journal of Human Resource Management, 16 (3): 345-365.

BVCA. 2006. The economic impact of private equity in the $U K$.

Conyon, M.J., Girma, S., Thompson, S., and Wright, P. 2001. Do hostile mergers destroy Jobs?, Journal of Economic Behaviour and Organization, 45: 427-440.

Conyon, M.J., Girma, S., Thompson, S., and Wright, P. 2002. The impact of mergers and acquisitions on company employment in the United Kingdom, European Economic Review, 46: 31-49.

Conyon, M., Girma, S., Thompson, S., and Wright, P. 2004. Do wages rise or fall following merger, Oxford Bulletin of Economics and Statistics, 66 (5): 847-862.

Davis, S.J., Haltiwanger, J., Jarmin, R., Lerner, J. and Miranda, J. 2008. Private equity and employment, available at: $\underline{\text { http://ssrn.com/abstract }=1107175}$ 
Denis, D. 1994. Evidence on the effects of hostile and friendly tender offers on employment, Managerial and Decision Economics, 15: 341-357.

Gokhale, J., Groshen, E.L., and Neumark, D. 1995. Do hostile takeovers reduce extramarginal wage payments?, Review of Economics and Statistics, 77 (3): 470-485.

Goergen M., Brewster, C., and Wood, G. 2006. The boundaries of governance: The effects of national setting and ownership changes on employees, ECGI Finance Working Paper, 136/2006.

Goergen, M., Brewster, C., and Wood, G. 2009. Corporate governance regimes and employment relations in Europe, Industrial Relations/Relations Industrielles, 64 (6): 620-640.

Gugler, K. and Yurtoglu, B.B., 2004. The effects of mergers on company employment in the USA and Europe, International Journal of Industrial Organization, 22: 481-502.

Guo, S., Hotchkiss, E. and Song, W. 2010. Do buyouts (still) create value?, Journal of Finance, forthcoming.

Harris, R., Siegel, D.S. and Wright, M. 2005. Assessing the impact of management buyouts on economic efficiency: Plant-level evidence from the United Kingdom, The Review of Economics and Statistics, 87 (1): 148-153.

Haveman, H., and Cohen, L. 1994. The ecological dynamics of careers, American Journal of Sociology, 100 (1): 104-152.

Jensen, M.C., 1986, Agency costs of free cash flow, corporate finance and takeovers, American Economic Review, 76: 323-330.

Jensen, M.C., 1989. Active investors, LBOs, and the privatisation of bankruptcy - statement before the House Ways and Means Committee, Journal of Applied Corporate Finance, 2: $35-44$. 
Jensen, M.C., 2006. Morgan Stanley roundtable on private equity and its import for public companies, Journal of Applied Corporate Finance, 18 (3), 9-37.

Jensen, M. C. 2010. Value maximization, stakeholder theory, and the corporate objective function, Journal of Applied Corporate Finance, 22 (1): 32-42.

Kaplan, S. 1989. The effects of management buyouts on operating performance and value, Journal of Financial Economics, 24:217-254.

Lichtenberg, F.R. and Siegel, D. 1990. The effects of leveraged buy-outs on productivity and related aspects of firm behaviour, Journal of Financial Economics, 27: 165-194.

Manne, H.G. 1965. Mergers and the market for corporate control, Journal of Political Economy, 73: 110-120.

Margolis, D. 2006. Should employment authorities worry about mergers and acquisitions?, Political Economy Journal, 5: 167-194.

McGuckin, R.H. and Nguyen, S.V. 2001. The impact of ownership changes: A view from labor markets, International Journal of Industrial Organization, 19: 739-762.

Nickell, S. 1984. An investigation of the determinants of manufacturing employment in the United Kingdom, Review of Economic Studies, 167, L1 (4): 529-558.

Redman, T. and Wilkinson, A. 2006. Downsizing, Redman, T. and Wilkinson, A. (eds.), Contemporary human resource management London: FT/Prentice Hall: 356-381.

Renneboog, L., Simons, T. and Wright, M. 2007. Why do public firms go private in the UK? The impact of private equity investors, incentive realignment and undervaluation, Journal of Corporate Finance, 13: 591-628. 
Rosett, J.G., 1990. Do union wealth concessions explain takeover premiums? The evidence on contract wages, Journal of Financial Economics, 27: 263-282.

Shleifer, A. and Summers, L. 1988. Breach of trust in hostile takeovers, in Auerbach A.J. (Ed), Corporate takeovers: Causes and consequences, University of Chicago Press, Chicago.

Simmel, G. 1981. On individuality and social forms. Chicago: University of Chicago Press.

Smart, S.B., and Waldfogel, J. 1994. Measuring the effect of restructuring on corporate performance: The case of management buyouts, The Review of Economics and Statistics, 76 (3): 503-511.

Sorge, R. 2005. The global and the local. Oxford: Oxford University Press.

Thornton, P. 2007. Inside the dark box: Shedding light on private equity. London: Work Foundation.

Tuch, C. and O'Sullivan, N., 2007. The impact of acquisitions on firm performance: A review of the evidence, International Journal of Management Reviews, 9 (2): 141-170.

Weir, C., Jones, P. and Wright, M. 2008. Public to private transactions, private equity and performance in the UK: An empirical analysis of the impact of going private. http://ssrn.com/abstract=1138616.

Wood, G. and Wright, M. 2009. Private equity: A review and synthesis, International Journal of Management Reviews, 11 (4): 361-380.

Wood, G. and Wright, M. 2010. Private equity and human resource management: An emerging agenda, Human Relations, 63 (9): 1279-1296. 
Wright, M., Renneboog, L., Simons, S., and Scholes, L. 2006. Leveraged buy-outs in the UK and Continental Europe: Retrospect and prospect, Journal of Applied Corporate Finance, 18 (3): $38-55$.

Wright, M., Burrows, A., Ball, R., Scholes, L., Meuleman, M. and Amess, K. 2007. The implications of alternative investment vehicles for corporate governance: A survey of empirical research, Report prepared for the Steering Group on Corporate Governance. Paris: OECD.

Wruck, K. 2008. Private equity, corporate governance, and the reinvention of the market for corporate control, Journal of Applied Corporate Finance, 20 (3): 8-21. 


\section{Table 1: Employment Effects of Management Buy-Outs/Private Equity Acquisitions}

\begin{tabular}{|c|c|c|c|c|}
\hline Author(s) (year) & Period of Study & Details of Sample & Country & Main Findings \\
\hline Kaplan (1989) & $1980-1986$ & $\begin{array}{c}76 \text { large management buy-outs } \\
\text { of public companies ( } 48 \text { of } \\
\text { which have post-buyout data on } \\
\text { employment) }\end{array}$ & US & $\begin{array}{l}\text { - No evidence of significant employment reductions post buy-out ( } 50 \% \text { of firms actually } \\
\text { increase employment). } \\
\text { - When divestments are taken into account, more than } 60 \% \text { of firms increase employment. } \\
\text { Overall, no evidence to support the notion that buy-out gains come from the firing of } \\
\text { employees. }\end{array}$ \\
\hline Lichtenberg and Siegel (1990) & 1981-1986 & \begin{tabular}{|}
12,896 manufacturing plants \\
linked to firms subject to large \\
$(>\$ 35)$ leveraged buy-outs. \\
Data involves matching buy-out \\
data with Census Bureau \\
Longitudinal Research Database
\end{tabular} & US & $\begin{array}{l}\text { - Evidence that post-buy-out there is reduction in the supervisor (non-production) to } \\
\text { production staff ratio. } \\
\text { - Evidence of an increase in the wage levels of production workers. }\end{array}$ \\
\hline Bacon, Wright and Demina (2004) & $\begin{array}{l}\text { Survey } \\
\text { undertaken in } \\
1998-99\end{array}$ & $\begin{array}{l}\text { Questionnaire survey of UK } \\
\text { firms experiencing an MBO } \\
\text { between 1994-97 (148 usable } \\
\text { responses) }\end{array}$ & UK & $\begin{array}{l}\text { - A significant proportion (often more than } 50 \% \text { ) of MBOs reported an increase in the } \\
\text { importance of HRM and the resources devoted to it after the MBO. } \\
\text { - Specific areas of improvement included: increased employment, greater employee } \\
\text { involvement, increased training, greater employee flexibility, more performance appraisals } \\
\text { and merit pay, and an increase in share ownership by staff. } \\
\text { - Both MBOs involving outside managers and those involving employees had a more } \\
\text { positive impact on employees than 'normal' incumbent manager-led MBOs. } \\
\text { The strategy of the MBO also impacts on HRM with customer-focused strategies being } \\
\text { more favourable to HRM development (compared to defensive-orientated MBOs). }\end{array}$ \\
\hline Harris, Siegel and Wright (2005) & 1982-1999 & $\begin{array}{c}\text { Plant-level data from } 4,877 \\
\text { plants involved in MBOs and } \\
30,875 \text { not involved in MBOs in } \\
\text { the UK }\end{array}$ & UK & $\begin{array}{l}\text { - Evidence that MBO plants were less efficient than others in the same industry orior to } \\
\text { MBO. } \\
\text { - After MBO, MBO plants are more efficient than their industry counterparts. } \\
\text { - Some evidence that the improved post-MBO effic iency may be largely due to a reduction } \\
\text { in the labour intensity of production due to the outsourcing of intermediate goods and } \\
\text { materials. }\end{array}$ \\
\hline $\begin{array}{c}\text { Bruining, Boselie, Wright and Bacon } \\
\text { (2005) }\end{array}$ & $\begin{array}{c}\text { Survey } \\
\text { undertaken } \\
\text { between 1999- }\end{array}$ & $\begin{array}{l}\text { Questionnaire survey of UK and } \\
\text { Dutch firms subject to an MBO } \\
\text { (between 1994-97 for UK and }\end{array}$ & $\begin{array}{c}\text { UK and } \\
\text { Netherlands }\end{array}$ & $\begin{array}{l}\text { - In both countries, there is evidence that MBOs have a positive impact on HR practices (e.g. } \\
\text { increases in training, employee involvement, the number of employees and pay levels). } \\
\text { - The impact is stronger in the non-institutionalised employment setting of the UK compared }\end{array}$ \\
\hline
\end{tabular}




\begin{tabular}{|c|c|c|c|c|}
\hline & 2001 & $\begin{array}{c}\text { between } 1992-98 \text { for the } \\
\text { Netherlands) }\end{array}$ & & $\begin{array}{l}\text { to the Netherlands. } \\
\text { However, HRM practices overall are still stronger in Dutch MBO firms compared to their } \\
\text { UK counterparts. }\end{array}$ \\
\hline Amess and Wright (2007) & 1999-2004 & $\begin{array}{l}\text { 1,350 LBO firms and a control } \\
\text { sample of } 4,029 \text { non-LBO firms }\end{array}$ & UK & $\begin{array}{l}\text { - In the case of all LBOs, there is no discernable difference in employment growth compared } \\
\text { to non-LBOs. } \\
\text { In the case of all LBOs, there is evidence of lower wage growth compared to non-LBOs. } \\
\text { - When segragated between MBOs and MBIs, MBOs have higher employment growth and } \\
\text { MBIs have lower employment growth compared to their matched samples. } \\
\text { Both MBOs and MBIs have a negative impact on wage growth compared to matched } \\
\text { firms. }\end{array}$ \\
\hline Amess, Brown and Thompson (2007) & 1998 & $\begin{array}{l}1959 \text { firms and } 27,263 \\
\text { employees from the UK's } \\
\text { Workplace Employment } \\
\text { Relations Survey }\end{array}$ & UK & $\begin{array}{l}\text { - MBO firms have lower levels of firm-level supervision when there is a higher proportion } \\
\text { of craft and skilled service. } \\
\text { - Employees in MBO firms have more discretion over their own work practices. }\end{array}$ \\
\hline $\begin{array}{l}\text { Bacon, Wright, Demina, Bruining and } \\
\text { Boselie (2008) }\end{array}$ & $\begin{array}{l}1998 \text { (UK) and } \\
2001 \\
\text { (Netherlands) }\end{array}$ & $\begin{array}{l}\text { Survey of firms involved in } \\
\text { MBOs in the UK (between } 1994 \\
\text { and 1997) and in the } \\
\text { Netherlands (between } 1992 \text { and } \\
\text { 1998) }\end{array}$ & $\begin{array}{l}\text { UK and The } \\
\text { Netherlands }\end{array}$ & $\begin{array}{l}\text { - Evidence that MBOs resulted in an increase in the number of high commitment practices } \\
\text { reported. } \\
\text { - Some evidence that the increase in the number of high commitment practices is less in the } \\
\text { case of private equity backed MBOs, but no evidence of a decrease. } \\
\text { UK MBOs show a more noticeable increase in the number of high commitment practices } \\
\text { after the MBO compared to MBOs in the Netherlands. However, this may disguise the } \\
\text { already high number of high commitment practices in firms in the Netherlands generally. }\end{array}$ \\
\hline $\begin{array}{c}\text { Davis, Haltiwanger, Jarmin, Lerner and } \\
\text { Miranda (2008) }\end{array}$ & $1980-2005$ & $\begin{array}{c}5,000 \mathrm{MBO} \text { firms and a control } \\
\text { sample of non-MBO firms }\end{array}$ & US & $\begin{array}{l}\text { - MBO firms have lower employment growth both before and after the MBO compared to a } \\
\text { matched sample of non-MBO firms. } \\
\text { - Up to three years after the MBO employment growth is significantly lower than the control } \\
\text { group but this reverses in years }+4 \text { and }+5 \text { when employment growth at MBO firms is } \\
\text { higher. } \\
\text { - Post-acquisition, the levels of hiring between MBO and non-MBO firms are similar but the } \\
\text { overall differences in employment are accounted for by the loss of existing jobs in MBO } \\
\text { firms, possibly due to closure/sale of unprofitable segments. } \\
\text { - Above findings relate to MBOs in retail trade, services and financial services but no } \\
\text { significant employment differences are identified between MBO and non-MBO firms in } \\
\text { general manufacturing. }\end{array}$ \\
\hline
\end{tabular}




\begin{tabular}{|c|c|c|c|c|}
\hline Weir, Jones and Wright (2008) & 1998-2004 & $\begin{array}{l}122 \text { firms involved in public-to- } \\
\text { private transactions }\end{array}$ & UK & $\begin{array}{l}\text { - No evidence that firms lose jobs immediately prior to going private. } \\
\text { - Loss of jobs after going private is at a lower rate than for firms in the same industry } \\
\text { remaining public. } \\
\text { - In years }+4 \text { and }+5 \text { after going private there is no evidence of job losses in contrast to firms } \\
\text { remaining public which exhibit job losses. } \\
\text { - Some evidence that going private firms increase employment but not getting back to pre- } \\
\text { transaction levels. }\end{array}$ \\
\hline Amess and Wright (2010) & 1993-2004 & $\begin{array}{l}533 \text { LBO firms and a control } \\
\text { sample of non-LBO firms }\end{array}$ & UK & $\begin{array}{l}\text { - No evidence of employment differences between LBO and non-LBO firms. } \\
\text { No evidence of employment differences between private equity backed LBO firms and } \\
\text { either non-private equity backed LBO firms or a control group of non-LBO firms. }\end{array}$ \\
\hline $\begin{array}{l}\text { Bacon, Wright, Scholes and Meuleman } \\
\qquad(2010)\end{array}$ & 2008 & $\begin{array}{l}\text { Survey of } 190 \text { private equity- } \\
\text { backed buy-outs companies } \\
\text { across Europe and interviews } \\
\text { with } 16 \text { managers of buy-out } \\
\text { companies. }\end{array}$ & $\begin{array}{l}\text { European } \\
\text { countries }\end{array}$ & $\begin{array}{l}\text { - PE investment does not result in changes to union recognition, membership density or } \\
\text { changes in management attitudes to union membership. } \\
\text { - Greater levels of employee consultation by management after PE transactions. }\end{array}$ \\
\hline
\end{tabular}


Table 2: Industrial classification of private equity acquisitions

Industry

Leisure

Retail

Software

Support Services

Restaurants and Pubs

Real Estate

Financial

Chemicals

Electrical and Electronics

Shipping and Ports

Food Processors

Media

Pharmaceuticals

Publishing and Printing

Water Supply

Other

Total
Number of Targets

8

8

8

8

6

5

4

3

3

3

2

2

2

2

2

7

73
31

32

33

34

35

36

37

38

39

40

41

42

43

44

45

46

47

48

49

50

51

52

53

54

55

56

57

58

59

60 
Table 3: Annual Breakdown of Private Equity Acquisitions and Control Companies

\begin{tabular}{|l|c|c|c|c|c|c|c|c|}
\hline Year & & 2000 & 2001 & 2002 & 2003 & 2004 & 2005 & 2006 \\
\hline No of Companies & $\begin{array}{c}\text { Sample } \\
\text { companies }\end{array}$ & 9 & 2 & 4 & 11 & 7 & 14 & 26 \\
\cline { 2 - 8 } & $\begin{array}{c}\text { Control } \\
\text { companies }\end{array}$ & 9 & 2 & 4 & 11 & 7 & 12 & 23 \\
\hline
\end{tabular}


Table 4: Availability of Data for Private Equity Acquisitions and Control Companies for Three Years Before and Three Years After the Acquisition

Year 0 is the year when the acquisition was completed.

\begin{tabular}{|l|c|c|c|c|c|c|c|c|}
\hline Year & -3 & -2 & -1 & 0 & +1 & +2 & +3 \\
\hline \multirow{2}{*}{$\begin{array}{l}\text { No of } \\
\text { Companies }\end{array}$} & $\begin{array}{c}\text { Sample } \\
\text { companies }\end{array}$ & 67 & 72 & 72 & & 48 & 50 & 42 \\
\cline { 2 - 9 } & $\begin{array}{c}\text { Control } \\
\text { companies }\end{array}$ & 63 & 63 & 63 & & 64 & 64 & 61 \\
\hline
\end{tabular}

14

15

16

17

18

19

20

21

22

23

24

25

26

27

28

29

30

31

32

33

34

35

36

37

38

39

40

41

42

43

44

45

46

47

48

49

50

51

52

53

54

55

56

57

58

59

60 
Table 5: $\quad$ Growth Rate in the Number of Employees and Number of Employees

The growth rate in the number of employees is the percentage growth rate in the average annual number of employees. Panel A contains the descriptive statistics for the sample companies as well as the control companies. The numbers in italic in Panel A are the numbers (levels) of employees. Panel B contains the tests for the differences in means (medians) between each year and the following year for the sample companies and the control companies, respectively. Panel C contains the tests for the differences in means (medians) between the sample companies and the control companies for each year. The asterisks indicate a 5\% (**) and 10\% (*) level of statistical significance.

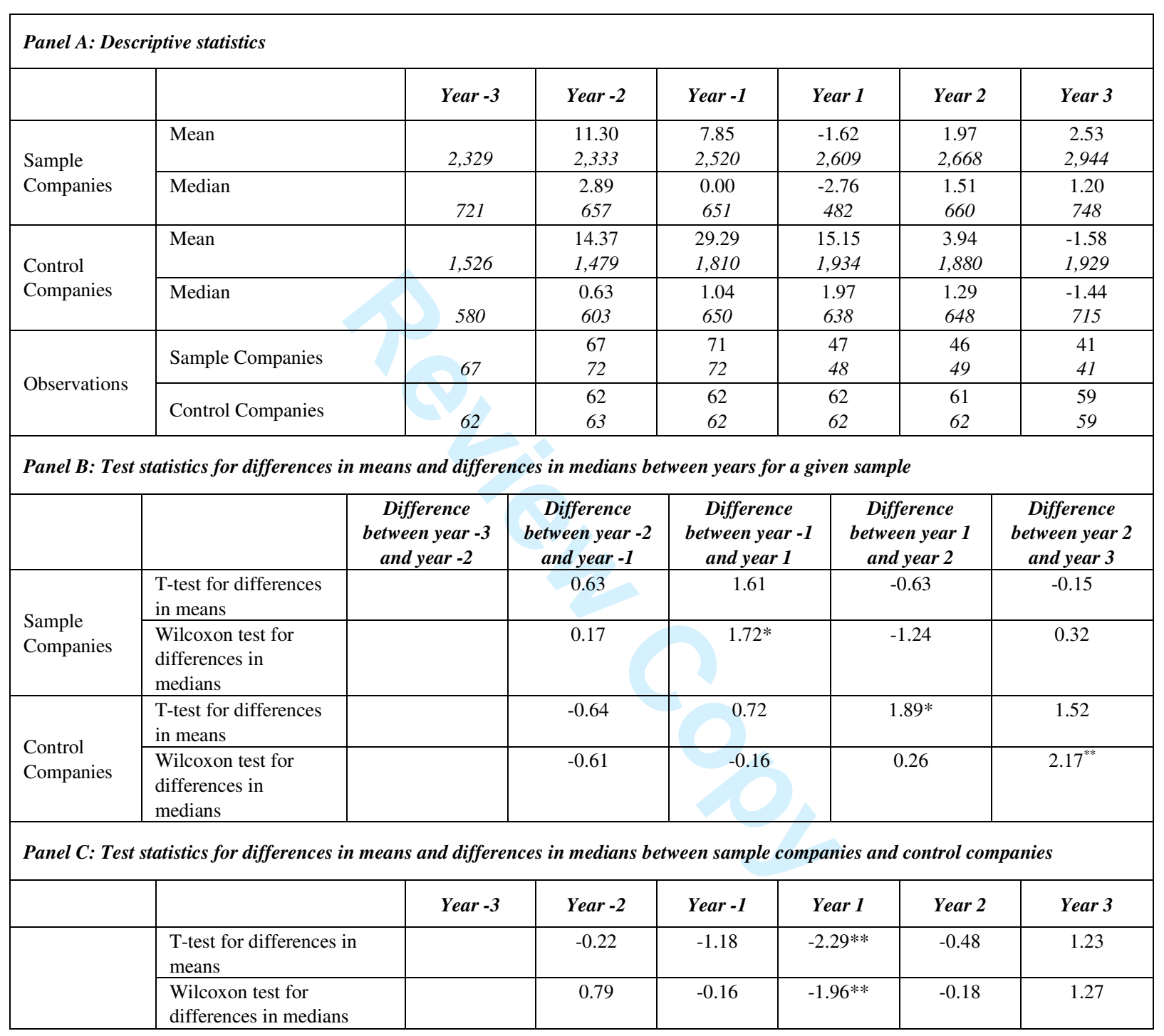


Table 6: $\quad$ Profit over Turnover

Profit is company profit before interest and taxation in $£ 000$ s and turnover is company turnover in $£ 000$ s. Profit/Turnover is in percentages. Panel A contains the descriptive statistics for the sample companies as well as the control companies. Panel B contains the tests for the differences in means (medians) between each year and the following year for the sample companies and the control companies, respectively. Panel $\mathrm{C}$ contains the tests for the differences in means (medians) between the sample companies and the control companies for each year. The asterisk indicate a $10 \%(*)$ level of statistical significance.

\begin{tabular}{|c|c|c|c|c|c|c|c|c|}
\hline \multicolumn{9}{|c|}{ Panel A: Descriptive statistics } \\
\hline & & Year -3 & Year -2 & Year -1 & & & Year 2 & Year 3 \\
\hline \multirow{2}{*}{$\begin{array}{l}\text { Sample } \\
\text { Companies }\end{array}$} & Mean & -18.76 & -2.63 & -11.52 & \multicolumn{2}{|c|}{-13.95} & 10.65 & 9.28 \\
\hline & Median & 8.77 & 9.59 & 9.35 & \multicolumn{2}{|c|}{6.74} & 4.61 & 6.05 \\
\hline \multirow{2}{*}{$\begin{array}{l}\text { Control } \\
\text { Companies }\end{array}$} & Mean & 3.11 & 8.73 & 10.87 & \multicolumn{2}{|c|}{15.69} & -4.22 & -21.63 \\
\hline & Median & 7.50 & 8.30 & 6.11 & \multicolumn{2}{|c|}{7.34} & 5.82 & 3.65 \\
\hline \multirow{2}{*}{ Observations } & Sample Companies & 67 & 72 & 72 & \multicolumn{2}{|c|}{47} & 49 & 41 \\
\hline & Control Companies & 63 & 63 & 63 & \multicolumn{2}{|c|}{63} & 63 & 60 \\
\hline \multicolumn{9}{|c|}{ Panel B: Test statistics for differences in means and differences in medians between years for a given sample } \\
\hline & & $\begin{array}{c}\text { Difference } \\
\text { between year }-3 \\
\text { and year }-2 \\
\end{array}$ & $\begin{array}{c}\text { Difference } \\
\text { between year }-2 \\
\text { and year }-1\end{array}$ & \multicolumn{2}{|c|}{$\begin{array}{c}\text { Difference } \\
\text { between year }-1 \\
\text { and year } 1 \\
\end{array}$} & \multicolumn{2}{|c|}{$\begin{array}{c}\text { Difference } \\
\text { between year } 1 \\
\text { and year } 2\end{array}$} & $\begin{array}{c}\text { Difference } \\
\text { between year } \\
2 \text { and year } 3 \\
\end{array}$ \\
\hline \multirow{2}{*}{$\begin{array}{l}\text { Sample } \\
\text { Companies }\end{array}$} & $\begin{array}{l}\text { T-test for differences } \\
\text { in means }\end{array}$ & -0.78 & 0.54 & \multicolumn{2}{|c|}{0.10} & \multicolumn{2}{|r|}{-1.10} & 0.16 \\
\hline & $\begin{array}{l}\text { Wilcoxon test for } \\
\text { differences in medians }\end{array}$ & -0.48 & 0.17 & \multicolumn{2}{|c|}{1.32} & \multicolumn{2}{|r|}{-0.61} & 0.17 \\
\hline \multirow{2}{*}{$\begin{array}{l}\text { Control } \\
\text { Companies }\end{array}$} & $\begin{array}{l}\text { T-test for differences } \\
\text { in means }\end{array}$ & -0.96 & -0.48 & \multicolumn{2}{|c|}{-0.54} & \multicolumn{2}{|r|}{$1.68^{*}$} & 0.71 \\
\hline & $\begin{array}{l}\text { Wilcoxon test for } \\
\text { differences in medians }\end{array}$ & -0.57 & 0.42 & \multicolumn{2}{|c|}{0.14} & \multicolumn{2}{|r|}{1.14} & 0.71 \\
\hline \multicolumn{9}{|c|}{ Panel C: Test statistics for differences in means and differences in medians between sample companies and control companies } \\
\hline & & Year -3 & Year -2 & Year -1 & \multicolumn{2}{|c|}{ Year 1} & Year 2 & Year 3 \\
\hline & $\begin{array}{l}\text { T-test for differences in } \\
\text { means }\end{array}$ & -1.07 & -1.11 & -1.48 & \multicolumn{2}{|c|}{-1.39} & 1.39 & -1.06 \\
\hline & $\begin{array}{l}\text { Wilcoxon test for } \\
\text { differences in medians }\end{array}$ & 0.55 & 0.75 & 0.83 & \multicolumn{2}{|c|}{-0.97} & 0.80 & 1.15 \\
\hline
\end{tabular}




\section{Table 7: $\quad$ Profit over Employees}

Profit is company profit before interest and tax in £000s. Employees is the annual average number of employees. Panel A contains the descriptive statistics for the sample companies as well as the control companies. Panel B contains the tests for the differences in means (medians) between each year and the following year for the sample companies and the control companies, respectively. Panel C contains the tests for the differences in means (medians) between the sample companies and the control companies for each year.

\begin{tabular}{|c|c|c|c|c|c|c|c|c|}
\hline \multicolumn{9}{|c|}{ Panel A: Descriptive statistics } \\
\hline & & Year -3 & Year -2 & Year -1 & & & Year 2 & Year 3 \\
\hline \multirow{2}{*}{$\begin{array}{l}\text { Sample } \\
\text { Companies }\end{array}$} & Mean & 24.20 & 27.38 & 18.25 & \multicolumn{2}{|c|}{15.07} & 34.28 & 28.19 \\
\hline & Median & 5.73 & 6.35 & 6.47 & \multicolumn{2}{|c|}{3.79} & 5.97 & 5.36 \\
\hline \multirow{2}{*}{$\begin{array}{l}\text { Control } \\
\text { Companies }\end{array}$} & Mean & 69.0 & 71.14 & 78.85 & \multicolumn{2}{|c|}{107.19} & 12.01 & -9.83 \\
\hline & Median & 6.30 & 8.98 & 7.95 & \multicolumn{2}{|c|}{6.78} & 5.72 & 4.50 \\
\hline \multirow{2}{*}{ Observations } & Sample Companies & 67 & 72 & 72 & \multicolumn{2}{|c|}{47} & 48 & 40 \\
\hline & Control Companies & 62 & 63 & 62 & \multicolumn{2}{|c|}{62} & 62 & 59 \\
\hline \multicolumn{9}{|c|}{ Panel B: Test statistics for differences in means and differences in medians between years for a given sample } \\
\hline & & $\begin{array}{c}\text { Difference } \\
\text { between year }-3 \\
\text { and year }-2\end{array}$ & $\begin{array}{c}\text { Difference } \\
\text { between year }-2 \\
\text { and year }-1\end{array}$ & \multicolumn{3}{|c|}{$\begin{array}{c}\text { Difference } \\
\text { between year }-1 \\
\text { and year } 1\end{array}$} & $\begin{array}{c}\text { Difference } \\
\text { between year } 1 \\
\text { and year } 2\end{array}$ & $\begin{array}{c}\text { Difference } \\
\text { between year } \\
2 \text { and year } 3\end{array}$ \\
\hline \multirow{2}{*}{$\begin{array}{l}\text { Sample } \\
\text { Companies }\end{array}$} & $\begin{array}{l}\text { T-test for } \\
\text { differences in means }\end{array}$ & -0.10 & 0.27 & \multicolumn{3}{|c|}{0.09} & -0.76 & 0.23 \\
\hline & $\begin{array}{l}\text { Wilcoxon test for } \\
\text { differences in } \\
\text { medians }\end{array}$ & -0.61 & 0.09 & \multicolumn{3}{|c|}{1.15} & -0.82 & 0.09 \\
\hline \multirow[b]{2}{*}{$\begin{array}{l}\text { Control } \\
\text { Companies }\end{array}$} & $\begin{array}{l}\text { T-test for } \\
\text { differences in means }\end{array}$ & -0.05 & -0.17 & \multicolumn{3}{|c|}{-0.46} & 1.16 & .21 \\
\hline & $\begin{array}{l}\text { Wilcoxon test for } \\
\text { differences in } \\
\text { medians }\end{array}$ & -1.16 & 0.46 & \multicolumn{2}{|c|}{-0.13} & & 0.96 & 0.35 \\
\hline \multicolumn{9}{|c|}{ Panel C: Test statistics for differences in means and differences in medians between sample companies and control companies } \\
\hline & & Year -3 & Year -2 & Year -1 & \multicolumn{2}{|c|}{ Year 1} & Year 2 & Year 3 \\
\hline & $\begin{array}{l}\text { T-test for differences in } \\
\text { means }\end{array}$ & -1.09 & -1.17 & -1.46 & \multicolumn{2}{|c|}{-1.51} & 0.30 & 0.37 \\
\hline & $\begin{array}{l}\text { Wilcoxon test for } \\
\text { differences in medians }\end{array}$ & 0.09 & -0.34 & -0.07 & & & 0.39 & 0.76 \\
\hline
\end{tabular}


Table 8: $\quad$ Turnover over Employees

Turnover is company turnover in $£ 000$ s. Employees is the annual average number of employees. Panel A contains the descriptive statistics for the sample companies as well as the control companies. Panel B contains the tests for the differences in means (medians) between each year and the following year for the sample companies and the control companies, respectively. Panel C contains the tests for the differences in means (medians) between the sample companies and the control companies for each year.

\begin{tabular}{|c|c|c|c|c|c|c|c|c|}
\hline \multicolumn{9}{|c|}{ Panel A: Descriptive statistics } \\
\hline & & Year -3 & Year -2 & Year -1 & \multicolumn{2}{|c|}{ Year 1} & Year 2 & Year 3 \\
\hline \multirow{2}{*}{$\begin{array}{l}\text { Sample } \\
\text { Companies }\end{array}$} & Mean & 138.98 & 144.48 & 144.10 & \multicolumn{2}{|c|}{147.60} & 166.54 & 159.52 \\
\hline & Median & 101.02 & 107.45 & 110.67 & \multicolumn{2}{|c|}{111.54} & 122.77 & 124.79 \\
\hline \multirow{2}{*}{$\begin{array}{l}\text { Control } \\
\text { Companies }\end{array}$} & Mean & 305.80 & 346.50 & 279.71 & \multicolumn{2}{|c|}{262.00} & 318.39 & 324.62 \\
\hline & Median & 99.40 & 110.86 & 113.58 & \multicolumn{2}{|c|}{123.41} & 137.86 & 135.39 \\
\hline \multirow[b]{2}{*}{ Observations } & Sample Companies & 67 & 72 & 72 & \multicolumn{2}{|c|}{48} & 49 & 41 \\
\hline & Control Companies & 62 & 63 & 62 & \multicolumn{2}{|c|}{62} & 62 & 59 \\
\hline \multicolumn{9}{|c|}{ Panel B: Test statistics for differences in means and differences in medians between years for a given sample } \\
\hline & & $\begin{array}{c}\text { Difference } \\
\text { between year }-3 \\
\text { and year }-2\end{array}$ & $\begin{array}{c}\text { Difference } \\
\text { between year }-2 \\
\text { and year }-1\end{array}$ & \multicolumn{2}{|c|}{$\begin{array}{c}\text { Difference } \\
\text { between year }-1 \\
\text { and year } 1\end{array}$} & \multicolumn{2}{|c|}{$\begin{array}{c}\text { Difference } \\
\text { between year } 1 \\
\text { and year } 2\end{array}$} & $\begin{array}{c}\text { Difference } \\
\text { between year } 2 \\
\text { and year } 3\end{array}$ \\
\hline \multirow{2}{*}{$\begin{array}{l}\text { Sample } \\
\text { Companies }\end{array}$} & $\begin{array}{l}\text { T-test for differences } \\
\text { in means }\end{array}$ & -0.16 & 0.01 & \multicolumn{2}{|c|}{-0.11} & \multicolumn{2}{|c|}{-0.61} & 0.22 \\
\hline & $\begin{array}{l}\text { Wilcoxon test for } \\
\text { differences in medians }\end{array}$ & -0.65 & -0.35 & \multicolumn{2}{|c|}{-0.46} & \multicolumn{2}{|c|}{-0.79} & -0.21 \\
\hline \multirow{2}{*}{$\begin{array}{l}\text { Control } \\
\text { Companies }\end{array}$} & $\begin{array}{l}\text { T-test for differences } \\
\text { in means }\end{array}$ & -0.24 & 0.41 & \multicolumn{2}{|c|}{0.14} & \multicolumn{2}{|c|}{-0.44} & -0.04 \\
\hline & $\begin{array}{l}\text { Wilcoxon test for } \\
\text { differences in medians }\end{array}$ & -0.70 & -0.19 & \multicolumn{2}{|c|}{-0.56} & \multicolumn{2}{|c|}{-0.82} & -0.26 \\
\hline \multicolumn{9}{|c|}{ Panel C: Test statistics for differences in means and differences in medians between sample companies and control companies } \\
\hline & & Year -3 & Year -2 & Year -1 & \multicolumn{2}{|c|}{ Year 1} & Year 2 & Year 3 \\
\hline & $\begin{array}{l}\text { T-test for differences in } \\
\text { means }\end{array}$ & -1.58 & -1.59 & -1.52 & -1 & & -1.36 & -1.27 \\
\hline & $\begin{array}{l}\text { Wilcoxon test for } \\
\text { differences in medians }\end{array}$ & -0.42 & -0.75 & -0.79 & -0 . & & 0.86 & 0.89 \\
\hline
\end{tabular}


Table 9: $\quad$ Wages over Employees

Wages is total wages and salaries in $£ 000$ s. Employees is the annual average number of employees. Panel A contains the descriptive statistics for the sample companies as well as the control companies. Panel B contains the tests for the differences in means (medians) between each year and the following year for the sample companies and the control companies, respectively. Panel $\mathrm{C}$ contains the tests for the differences in means (medians) between the sample companies and the control companies for each year.

\begin{tabular}{|c|c|c|c|c|c|c|c|c|}
\hline \multicolumn{9}{|c|}{ Panel A: Descriptive statistics } \\
\hline & & Year -3 & Year -2 & Year -1 & Yed & & Year 2 & Year 3 \\
\hline \multirow{2}{*}{$\begin{array}{l}\text { Sample } \\
\text { Companies }\end{array}$} & Mean & 30.08 & 32.03 & 34.46 & \multicolumn{2}{|c|}{32.31} & 34.09 & 33.80 \\
\hline & Median & 24.95 & 24.30 & 24.51 & \multicolumn{2}{|c|}{26.14} & 27.62 & 27.79 \\
\hline \multirow{2}{*}{$\begin{array}{l}\text { Control } \\
\text { Companies }\end{array}$} & Mean & 34.80 & 35.50 & 33.72 & \multicolumn{2}{|c|}{44.34} & 46.73 & 49.32 \\
\hline & Median & 26.12 & 26.49 & 25.52 & \multicolumn{2}{|c|}{27.67} & 31.19 & 35.13 \\
\hline \multirow[b]{2}{*}{ Observations } & Sample Companies & 67 & 72 & 72 & \multicolumn{2}{|c|}{48} & 49 & 41 \\
\hline & Control Companies & 62 & 63 & 62 & \multicolumn{2}{|c|}{62} & 62 & 59 \\
\hline \multicolumn{9}{|c|}{ Panel B: Test statistics for differences in means and differences in medians between years for a given sample } \\
\hline & & $\begin{array}{c}\text { Difference } \\
\text { between year }-3 \\
\text { and year }-2\end{array}$ & $\begin{array}{c}\text { Difference } \\
\text { between year }-2 \\
\text { and year }-1\end{array}$ & \multicolumn{2}{|c|}{$\begin{array}{c}\text { Difference } \\
\text { between year }-1 \\
\text { and year } 1\end{array}$} & \multicolumn{2}{|c|}{$\begin{array}{c}\text { Difference } \\
\text { between year } 1 \\
\text { and year } 2\end{array}$} & $\begin{array}{c}\text { Difference } \\
\text { between year } \\
2 \text { and year } 3\end{array}$ \\
\hline \multirow{2}{*}{$\begin{array}{l}\text { Sample } \\
\text { Companies }\end{array}$} & $\begin{array}{l}\text { T-test for differences } \\
\text { in means }\end{array}$ & -0.51 & -0.53 & \multicolumn{2}{|c|}{0.43} & \multicolumn{2}{|r|}{-0.42} & 0.07 \\
\hline & $\begin{array}{l}\text { Wilcoxon test for } \\
\text { differences in medians }\end{array}$ & -0.29 & -0.43 & \multicolumn{2}{|c|}{-0.08} & \multicolumn{2}{|r|}{-0.74} & -0.13 \\
\hline \multirow{2}{*}{$\begin{array}{l}\text { Control } \\
\text { Companies }\end{array}$} & $\begin{array}{l}\text { T-test for differences } \\
\text { in means }\end{array}$ & -0.09 & 0.29 & \multicolumn{2}{|c|}{-1.14} & \multicolumn{2}{|r|}{-0.21} & -0.23 \\
\hline & $\begin{array}{l}\text { Wilcoxon test for } \\
\text { differences in medians }\end{array}$ & -0.43 & -0.24 & \multicolumn{2}{|c|}{-1.08} & \multicolumn{2}{|r|}{-0.82} & -0.42 \\
\hline \multicolumn{9}{|c|}{ Panel C: Test statistics for differences in means and differences in medians between sample companies and control companies } \\
\hline & & Year -3 & Year -2 & Year -1 & \multicolumn{2}{|c|}{ Year 1} & Year 2 & Year 3 \\
\hline & $\begin{array}{l}\text { T-test for differences in } \\
\text { means }\end{array}$ & -0.78 & -0.60 & 0.15 & \multicolumn{2}{|c|}{-1.17} & -1.42 & -1.46 \\
\hline & $\begin{array}{l}\text { Wilcoxon test for } \\
\text { differences in medians }\end{array}$ & -0.10 & -0.26 & -0.09 & \multicolumn{2}{|c|}{-0.98} & -1.16 & -1.29 \\
\hline
\end{tabular}


Table 10: $\quad$ Differences in Unexpected Performance Improvements

The performance measure is profit over turnover. Profit is company profit before interest and taxation in £000s and turnover is company turnover in $£ 000$ s. Profit/Turnover is in percentages. The difference in unexpected performance improvements is defined as the difference between the actual performance in a given year and the mean for the analysts' performance forecast for a sample firm minus the equivalent difference for the same year for the sample firm's control firm. Following Smart and Waldfogel (1994), the performance forecasts are all made in the year preceding the acquisition, i.e. year -1. Panel A contains the descriptive statistics for the sample companies as well as the control companies. Panel B contains the tests for the differences in means (medians) between each year and the following year for the sample companies and the control companies, respectively. Panel $\mathrm{C}$ contains the tests for the differences in means (medians) between the sample companies and the control companies for each year.

\begin{tabular}{|c|c|c|c|}
\hline \multicolumn{4}{|c|}{ Panel A: Descriptive statistics } \\
\hline & Year 1 & Year 2 & Year 3 \\
\hline Mean & 1.24 & 2.01 & -0.71 \\
\hline Median & -0.02 & -0.01 & -0.71 \\
\hline Observations & 14 & 9 & 1 \\
\hline \multicolumn{4}{|c|}{ Panel B: Test statistics for differences in means and differences in medians between years for a given sample } \\
\hline & Year 1 & Year 2 & Year 3 \\
\hline $\begin{array}{l}\text { T-test for differences in } \\
\text { means }\end{array}$ & 0.86 & 1.03 & - \\
\hline $\begin{array}{l}\text { Wilcoxon test for } \\
\text { differences in medians }\end{array}$ & -0.22 & 0.53 & -1.00 \\
\hline
\end{tabular}

